\title{
JOHN MACKIE
}

We regret to record the death of Dr John Mackie in January 1955. He had been Recto? of Leith Academy Secondary School for twenty years and had only retired in February 1953. His ability in mathematics and interest in education were widely known. His unfailing friendliness and kindliness made him beloved by all.

John Mackie, Dux of Leith Academy in 1902, decided to enter the teaching profession by becoming a pupil-teacher under the Leith School Board. He proceeded to the training college and the University of Edinburgh, where he showed that his scholarship was well above average. He graduated M.A. with first class honours in mathematics and natural philosophy, and B.Sc. with special distinction in natural philosophy. He was elected a Fellow of the Royal Society of Edinburgh in 1928, and a Fellow of the Educational Institute of Scotland in 1938. He had held the office of President of the Edinburgh Mathematical Society and was an Associate of the British Psychological Society.

For a thesis, which he submitted in 1929, Edinburgh University awarded him the degree of Doctor of Science. Members of the Society will know of his creative work in mathematics.

Apart from the few years spent on active service with the Royal Scots Regiment during the First World War, and a period spent in a University post in Edinburgh, Dr Mackie's professional life was spent in schools in Leith. From Principal Teacher of Mathematics in Leith Academy he was appointed Rector in 1933. As pupil, pupilteacher, principal teacher, rector of a school which he loved, in a town where he was brought up and of whose history and tradition few men were more knowledgeable, he was found to be a quiet-voiced, patient and kindly gentleman. Staff, pupils and former pupils held him in high esteem and affection.

Wider aspects in education were served by Dr Mackie in his work with the Edinburgh Provincial Committee, with the Local and National Councils of the Educational Institute of Scotland, and with the Head Teachers' Committee.

His interests were many and all benefited by his personality and his high sense of spiritual values. 
At a dinner, held in Leith Academy when he retired, Dr Mackie was presented with his portrait, painted in oils by Mr Donald Moodie. We wished him many years of continued happiness. Unfortunately illness marred the too-short period of retirement and he died in Jantary 1955.

Our deepest sympathies are conveyed to Mrs Mackie and her son and daughter.

\section{T. M. M. Allen.}

\section{W. M. H. GREAVES}

William Michael Herbert Greaves was born, 1897, September 10, in Barbados; his family came from the west of England. He had a brilliant career in mathematics and astronomy at Cambridge where he was Tyson Medallist 1919, Smith's Prizeman 1921, Isaac Newton Student 1921-3, and Fellow of St John's College 1922. He was Chief Assistant at the Royal Observatory, Greenwich, 1924-38. He was then appointed Astronomer Royal for Scotland and Professor of Astronomy in the University of Edinburgh. He was elected F.R.S. in 1943. He died suddenly in Edinburgh on Christmas Eve 1955. In 1926 he married Miss Caroline Grace Kitto, who survives him with their son.

Greares was Secretary of the Royal Astronomical Society, 1933-39 and later filled the office of President with great distinction, 1947-49. He had been Secretary and Recorder of Section A of the British Association. He had attended all of the general assemblies of the International Astronomical Union since 1935 and had been President of its commission on stellar photometry, 1948-55 and a very active member of other commissions. In the Royal Society of Edinburgh, he was Secretary 1940-45, Vice-President 1946-49, and Chairman of the Robert Cormack Bequest Fund Committee.

Before going to Greenwich, Greaves's work was entirely mathematical and in his early researches he had the advice of $\mathrm{H}$. F. Baker, F.R.S. He always retained an appreciation of neat or powerful mathematical reasoning. In celestial mechanics, he made contributions to the restricted three-body problem, the theory of Saturn's rings and to problems in perturbation theory. At Greenwich, the part of the Chief Assistant was to foster the research aspects of the Observatory's work both by initiating new investigations and by consultation on those 